\title{
The Analysis of Target Achievement in Bank Indonesia 2015 Regulation on Lending for Micro, Small and Medium Enterprises
}

\author{
Kenny Putri Lisa \\ Faculty of Economics and Business \\ Universitas Indonesia \\ Indonesia \\ kennyputri93@gmail.com
}

\author{
Dewi Ratna Sjari Martokoesoemo \\ Department of Economics \\ Faculty of Economics and Business Universitas Indonesia \\ Indonesia \\ pinkmarto@gmail.com
}

\begin{abstract}
Micro, Small and Medium Enterprises (MSME) are important sectors in the economy, especially for developing countries. One of the biggest obstacles towards developing the sector is related to financing. Bank Indonesia has launched the regulation called Bank Indonesia's Policy/Peraturan Bank Indonesia (PBI) 2015 stating that all commercial banks must allocate $20 \%$ of the total credit for MSMEs loan. Panel regression models are used to show that Non Performing Loan (NPL) and Third Party Fund (TPF) affect the credit supply for MSMEs. Moreover, the results show that Foreign Bank and Joint-Venture Bank are still far from the target.
\end{abstract}

Keywords—MSME; bank; credit

\section{INTRODUCTION}

Micro, Small and Medium Enterprise (MSME) sector plays an important role in developing a country. In Indonesia, likes many other developing countries, MSME is the backbone of the economy. This sector survived the economic crises in 1997 and 2008 showing that MSME sector is relatively resistant to shock in various economic situations. Additionally MSME is also one of the greatest contributing sectors to Indonesian GDP; it contributed as much as 60.34\% in 2013.

The data shows that MSME sector can grow quite rapidly, but undoubtedly need to be supported continually for the MSME's progress itself. Various government regulations have been issued to support the progress of MSME but frequently there are several obstacles in its implementation. One of the obstacles found in the implementation is related to financing. In fact, according to [1] small enterprises such as MSME is a very vulnerable field because of the dependence on financial institution in financing their businesses. In this case, financial institution may be formal or non formal institution, as well as bank or non bank institution.

Bank as an intermediary institution certainly is assigned to channel the third party's funding that is managed in the form of credit to the parties in need, i.e. MSME. MSME credit in one way is to support the growth of MSME in Indonesia. According to data from Otoritas Jasa Keuangan
$(O J K) /$ Financial Services Authority (FSA), MSME credit growth year on year (yoy) was recorded to be increasing. In July 2016, MSME credit growth reached $10.1 \%$ and in the current year it was higher than the overall credit growth at $8.3 \%[2]$.

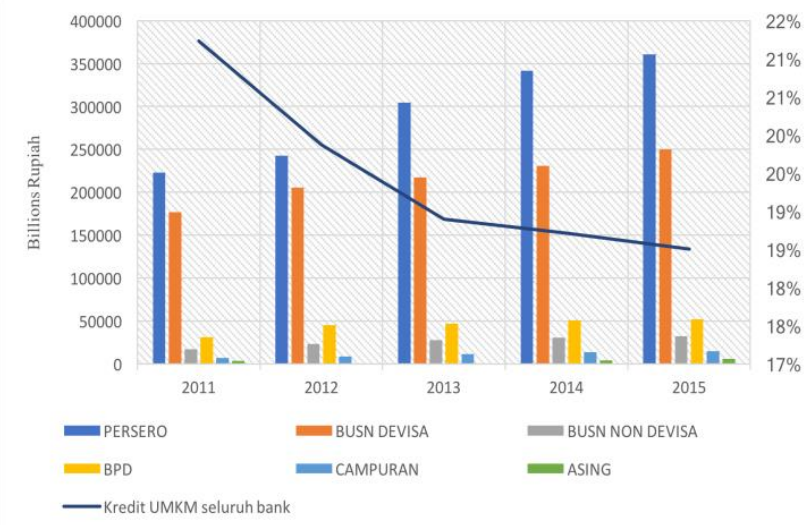

Fig 1. Distribution of MSME Credit by Commercial Banks (in billions) Source: Bank Indonesia's MSME Credit Report

As seen in Fig. 1. the average proportion of MSME to the total credit is only less than $19 \%$, with the largest distribution by state-owned bank group. In 2015 Bank Indonesia issued Bank Indonesia Regulation No. 17/12/PBI/2015 (PBI 2015) on Amendment of Bank Indonesia Regulation No 14/22/PBI/2012 (PBI 2012), titled Concerning Credit or Financing by Commercial Banks and Technical Assistance to Develop Micro, Small, and Medium Enterprises. This regulation stated that Commercial Bank has the obligation to allocate at least $20 \%$ of the total credit towards MSME. This level should be applied gradually starting with a minimum $5 \%$ in 2015 and reach in a minimum of $20 \%$ in 2018 . To evaluate the possibility of the target set in PBI 2015, it needs to know how the banks distribute MSME credit. This paper examines the factors that influence banks in distributing MSME credit so that the possibility of all commercial bank groups in Indonesia achieve the target by 2018 can be evaluated. 


\section{THEORETICAL REVIEWS}

The definition of credit can be found in the Republic of Indonesia Law No. 10 of 1998 Concerning Banking; stating that "credit is the provision of money or claim that can be equivalent to it, based on a loan and borrowing agreement between bank and other party that put the obligation on the recipient of the loan to pay the debt after a certain length of time with a given interest." According to [3], bank credit is classified into two components: loan and investment. The classification also illustrates the amount of marginal cost required to obtain information about the credit to be granted by the bank. Credits disbursed by banks are further divided into three: consumer credit, investment credit, and working capital credit. This paper particularly discusses the MSME credits which cover only credit for investment and for working capital.

By the definition given by Bank Indonesia, MSME credit is the credit disbursed by commercial banks to micro, small and medium enterprises debtors that meet the definition and criteria of MSME as regulated by the Law No. 20 of 2008 concerning MSME. Credit disbursement or financing of MSME by commercial banks is carried out indirectly among others by executing pattern cooperation, channeling pattern, and co-financing.

MSME Credit itself is subdivided into medium enterprise credit, micro enterprise credit, and small enterprise credit. Based on MSME credit report in 2015, the largest percentage of credit being channeled to medium enterprises was $47.2 \%$; whereas micro and small enterprises received $24 \%$ and $28.8 \%$ respectively. The domination of the medium enterprise credit was mainly due to the fact that this sector had greater assets as collateral in applying for credits at the banks.

\section{A. Credit Rationing}

Credit market is unlike other common markets where the price generally becomes a signal for the seller and the buyer to make transactions, and where the information is almost perfectly accepted by both the seller and the buyer. In the credit market, the imperfect information prevents the interest rate (the price of money) indicating the balance of demand and supply. The imperfect information from the lender to the client (borrower) results in only some clients being able to get the loan. Literally, credit rationing means credit allotment. Jaffee (1969) [4] stated that credit rationing is a result of an excess of credit demands; whereas [5] said that credit rationing occurs when a bank rejects the loan even when the lender complies with higher interest rate. Stiglitz and Weiss (1981) [6] showed that although the demands on loan kept increasing, nevertheless when it reached a certain interest rate, the bank no longer increased the rate and actually began to decrease the interest rate to its effective level. As the demands exceed the supply, the lender will limit the loan (credit rationing)

Stiglitz and Weiss (1981) [6] and [5] also mentioned that credit rationing was one of the ways in which banks dealt with adverse selection and moral hazard issues. Credit rationing consists of two forms: the first one occurs when the party granting the loan refuses to grant a loan even when the grant seeker agrees to pay high interest; the second one occurs when the party granting the loan is willing to grant limited amount of loan. The first form is similar to non price credit rationing [7]. Non price credit rationing can be experienced by small entrepreneurs who asked for a loan from the bank. Some of the borrowers manage to get loans while others with similar level of creditworthiness do not [7]. Adverse selection issue means that the bank has the perception that only low quality clients are willing to pay high interest rate. As a result, the bank tends to be more cautious in channeling the credit and no longer considers the interests rates as the main factor for determining loans as shown in Fig. 2.

Fig. 2. shows that non price credit rationing can decrease the credit offered by the bank. At first, the balance of credit demanded is in line $\mathrm{D}$ and the loanable funds supplied by $\mathrm{S}_{0}$ so that credit quantity $\mathrm{L}$ is formed with interest rate $\mathrm{r}$. However, due to moral hazard and adverse selection, the bank as the party having the ability to influence the amount of credit given, creates a shift from $S_{0}$ to $S_{1}$ and subsequently affects the amount of credit granted as well as the interest rate. However, when the non-price credit rationing phenomenon occurs, the interest rate gradually stops being the factor for loan granting and the curve $S_{1}$ is replaced by the inelastic curve $\left(S_{2}\right)$.

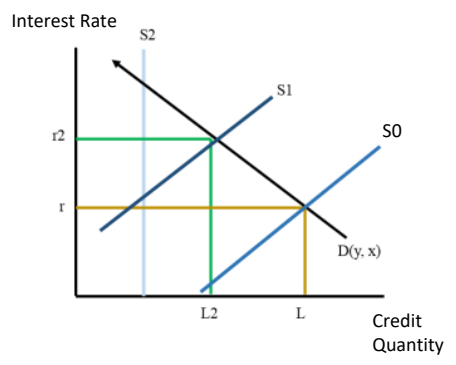

Fig 2. Non Price Credit Rationing

Hence neither high interest rate nor high collateral increases the supply of loanable fund. Under such circumstances, the credit restrictions are realized by limiting the total bank loan, instead of reducing the loan of each customer or increasing interest rate in line with the size of loan.

This also happens in the MSME credit market in Indonesia. The government regulation on KUR (Kredit Usaha Rakyat or People's Business Credit) with 9\% interest is one way to reduce the adverse selection that will exclude MSME with small collateral; while credit rationing will cause the interest rate to be too high for MSME. The government's guarantee of subsidies and insurance is expected to put pressure on both of the above, provide greater access for MSME to obtain working capital and funding for their investment.

\section{B. Previous Research}

Rao et al. (2006) [8] examined the behavior of banks in distributing credits for small enterprises like MSME. The research looked at the effects of the size and performance of the bank on the credit given to Small Scale Industry (SSI) sector. The size of the banks was classified into four (4) groups: State Bank of India and its associates (SBIA), Nationalized Banks (NB), foreign banks (FB), and other commercial banks (OSCB). Next, the banks were grouped 
based on their assets, i.e. small, medium and large banks. Performance variable was based on the Return on Asset (RoA), spread or the ratio of net interest margin to total asset, Non-Performing Asset (NPA) of SSI credit, and capital to risk-weighted assets ratio (CRAR). Results showed that the bank size, NPA of SSI credit, and RoA significantly affected the proportion of MSME credit distribution.

Similar research was conducted by [9] on a sample of banks in Asia. They aimed to identify the impacts of foreign banks on MSME credit distribution. One of the claims was that countries with national banks that owned large market share would be distributing less MSME credit. Looking for evidence at such behavior in Indonesia, it was actually the national bank that distributed largest MSME credit. Viverita et al. [9] used panel data for the regression model with the bank performance indicator such as NPL and CAR, as its variables.

An investigation of bank behavior towards credit distribution was done in Indonesia by [10] using the CournotOligopoly model. Variabels used in the model were similar to those in [8], including Non Performing Loan (NPL) and CRAR variable or comonly known as Capital Adequacy Ratio (CAR). Their results showed that the credit interest rate and deposit rate negatively affected credit supply. The market share indicated that banking structure was oligopolist. Banking internal condition is such as CAR, NPL, the Third Party Fund (TPF).

This research aims to recognize the behavior of each bank groups. Several studies examined how the size of the bank affects MSME credit distribution. The study of [11] found that MSME credit distribution was mostly conducted by small-size banks and whether the factor of total assets of the bank had an impact on MSME credit distribution or not. However in Indonesia, existing data indicate that MSME credit distribution is done predominantly by state-owned banks where the bank group had the largest assets. The aim of the current paper is to examine this effect/behavior in Indonesia.

\section{MSME Credit and KUR}

Indonesia has a long and rich history of various microfinancing types, products and a numbers of executing agencies. One foundation of government microfinancing regulation which has the widest coverage is People's Business Credit (Kredit Usaha Rakyat or KUR). KUR is a program launched by the government through the National Team for the Acceleration of Poverty Alleviation (TNP2K) in November 2007. Banks that become KUR suppliers will be given interest subsidies and insured for loans disbursed. Initially KUR is channeled by state-owned banks, BPR and BPD which have been appointed by the government. Although it is aimed to poverty alleviation, the KUR interest rate initially does not differ much with the interest rate of other commercial loans, which is $24 \%$.

In May 2015 the government issued a new type of KUR product scheme, KUR Mikro. This MSME loan charged an effective end-user rate of $21 \%$ per annum. Then to boost the economy through greater access of MSME to credit, the government decided to cut KUR interest rate to $12 \%$ effective per year in July 2015. In addition to interest subsidy on channeling banks, the government also guarantee KUR Mikro loan through Jamkrindo. The number of KUR channeling banks is increasing steadily in line with the Minister of Economy No. 13 of 2015 which explains the changes in the KUR system by emphasizing the use of SIKP (Credit Information System Program) for data collection of all KUR customers in Indonesia. Through this rule, every bank and nonbank financial institution, which passed the examination of the Financial Services Authority (Otoritas Jasa Keuangan or OJK) and the Ministry of Finance, can become a KUR dealer, thus expanding the community's access to KUR. This regulation becomes the legal basis for reducing interest rates charged to debtors from $12 \%$ in 2015 to $9 \%$ at the beginning of 2016 which is expected to further encourage MSME enterprises to increase their investment through bank loans. This loan facility for MSMEs is also expected to help commercial banks to achieve their target by $20 \%$ of loans for MSMEs in accordance with $\mathrm{BI}$ regulations mentioned above.

\section{RESEARCH METHOD}

\section{A. Determinants in MSME Credit Distribution}

In recognizing banking determinant in MSME credit distribution, the variable of banking internal condition is being used. The variable is chosen because usually banks' good internal condition is followed by improvement of intermediacy function of the bank. In other words, level of financial distribution to the public is also getting better.

Several variables used in previous researches were adapted to be applied in this research and added variables considered as appropriate. There are two (2) regression models used in this research as follow:

Model 1 :

$\% M S M E_{i t}=\beta_{0}+\beta_{1} N P L_{i t}+\beta_{2} \operatorname{lnTPF} F_{i t}+\beta_{3}$ Spread $_{i t}+$ $\beta_{4} R_{0} A_{i t}+\beta_{6}$ SBI Rate $i t+D B_{i t}+\varepsilon_{i t} \quad \ldots \ldots \ldots \ldots \ldots \ldots \ldots . . .(1)$

\section{Model 2 :}

$M S M E_{i t}=\beta_{0}+\beta_{1} N P L_{i t}+\beta_{2} \operatorname{lnTPF}_{i t}+\beta_{3}$ Spread $_{i t}+$

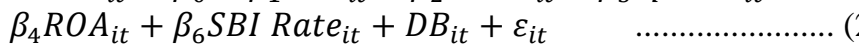

NPL is a non-performing loan; TPF is the third party fund; Spread is difference between interest for deposit and loan; ROA is return on assets; SBI Rate is Bank Indonesia's Certificate; and DB is dummy variable for each group of banks. The two models differ in the dependent variable. In model 1 , the dependent variable is the proportion of MSME credit distribution to total credit. In model 2, the amount of MSME's debit credit tray was used as dependent variable. The first model was used to estimate MSME credit distribution in 2018, whereas the second model compared whether there were any differences when using different dependent variable. The hypotheses are defined below. 
TABLE I. HYPOTHESES AND SIGN BETWEEN INDEPENDENT VARIABLES AND DEPENDENT VARIABLE

\begin{tabular}{|c|c|}
\hline Independent Variable & Expected Relationship between the Independent Variable and the Dependent Variable \\
\hline $\begin{array}{l}\text { Micro Small and Medium } \\
\text { Enterprises Nonperforming Loan } \\
\text { (MSME NPL) }\end{array}$ & $\begin{array}{l}\text { Negatively Related to MSME credit } \\
\text { NPL illustrated the percentage of problematic credit amount to credit issued by the bank. It means that the higher the } \\
\text { NPL the lesser credit is distributed by the bank. }\end{array}$ \\
\hline Return on Assets (ROA) & $\begin{array}{l}\text { Positively related to MSME credit } \\
\text { ROA is the performance indicator of a bank. It is calculated by dividing the bank's net income by its average total } \\
\text { assets. Larger the ROA is expected to correspond to larger credit approved. }\end{array}$ \\
\hline Third Party Fund (TPF) & $\begin{array}{l}\text { Positively related to MSME credit } \\
\text { Complying with the bank's main function, to manage saving and investment funds from their clients. The more fund } \\
\text { stored in the bank, the more credit will be distributed. }\end{array}$ \\
\hline Spread & $\begin{array}{l}\text { Positively related to MSME credit } \\
\text { Spread is the difference between a bank's lending rate and its deposit rate. The larger the spread, the more revenue is } \\
\text { being obtained by the bank so it is willing to distribute more MSME credit. }\end{array}$ \\
\hline $\begin{array}{l}\text { Indonesia's Central Bank Certificate } \\
\text { (SBI) rate }\end{array}$ & $\begin{array}{l}\text { Negatively Related to MSME credit } \\
\text { When the nominal of SBI owned by each bank is increasing it means that the credit distribution to the public is lower. } \\
\text { This happens because the SBI purchase and credit distribution are both banking activities and have substitutive nature. }\end{array}$ \\
\hline Dummy variables for bank's group & $\begin{array}{l}\text { Negatively Related to MSME credit } \\
\text { MSME credit distribution by the groups of foreign exchange private national banks, non-foreign exchange private } \\
\text { national banks, joint venture banks, foreign banks, and regional development banks is smaller than that of the state } \\
\text { owned banks }\end{array}$ \\
\hline
\end{tabular}

\section{B. The Projection of MSME Credit Distribution}

The Fixed Effect Least Square Dummy Variable (LSDV) method is applied to examine the behavior of each bank group toward MSME credit distribution in comparison to the reference base which is the State Owned Bank. The State Owned Bank is used as a reference because it reached target set by the central bank.

After obtaining the equation in MSME credit distribution by making panel data regression, the second question will be answered using several conditions. The conditions to be applied are when the bank is considered to be (1) Low Performance, (2) Medium Performance, and (3) High Performance. Low performance is when the bank performance, viewed from the research's independent variable model, is in its bad condition. Medium performance is when the bank performance is as it was previously, i.e. in 2015. High performance is when improvement occurs in the bank performance and reaches the best bank performance point. The figures used in making the projection are the figures that illustrate the condition obtained from the data during the period of 2011 to 2015. For instance, in optimistic condition, the NPL figures used are the smallest NPL figures during five years period, and so on. Actually there is another thing that can be included in optimistic condition which is when the bank decides to provide more training to MSME so that MSME can be more bankable and be better in managing their finance; so that the rate of returning bank loan can be better.

\section{RESULTS AND DISCUSSION}

Quarterly data for 6 bank groups are used including long panel data type where the amount of $\mathrm{T}$ (time) is more than the number of N (individuals). Gujarati \& Porter (2009) [12] mentioned that by having long panel data, the use of FEM or
REM models has very minor difference. Thus, in this research the appropriate model to be applied is FEM.

TABLE II. TEST RESULT OF FIXED EFFECT MODEL REGRESSION

\begin{tabular}{|l|c|c|}
\hline \multicolumn{1}{|c|}{ VARIABLES } & (\% MSME) & (In MSME) \\
\hline$N P L$ & Model 1 & Model 2 \\
\hline$T P F$ & $-0,136 * *$ & $-10,38 * * *$ \\
\hline$R O A$ & $-0,0267 * * *$ & $0,657 * * *$ \\
\hline SPREAD & 0,296 & 6,473 \\
\hline SBI Interest Rate & $-0,0993$ & $-13,14 * * *$ \\
\hline $\begin{array}{l}\text { Foreign Exchange Private } \\
\text { National Bank }\end{array}$ & $-0,102$ & $-0,113$ \\
\hline $\begin{array}{l}\text { Non Foreign Exchange Private } \\
\text { National Bank }\end{array}$ & $-0,0818^{*} * *$ & $-0,499 * * *$ \\
\hline Joint Venture Bank & $-0,263 * * * *$ & $-0,901 *$ \\
\hline Foreign Bank & $-0,302 * * *$ & $-3,707 * * *$ \\
\hline Regional Development Bank & $-0,110 * * *$ & $-0,772 * * *$ \\
\hline Constant & $0,641 * * *$ & 4,011 \\
\hline Observations & 114 & 114 \\
\hline Number of bank & 6 & 6 \\
\hline$R$-square (overall) & 0,9851 & \\
\hline Prob > chi2 & 0.000 & \\
\hline \multicolumn{2}{|c|}{ Standard errors in parentheses $* * * p<0,01, * * p<0,05, * p<0,1$} \\
\hline
\end{tabular}

From the result of regression on the two models, there are several differences in figures and coefficient direction. In model 1, there are only two significant variables: MSME NPL and TPF at the level of confidence reaching 95\% and 99\%. In model 2, when the dependent variable used was in of the nominal of MSME credit, there are three significant independent variables: MSME NPL, TPF, and Spread. Rsquare on the model is quite large i.e. 0.9851 therefore the model can be used to estimate the target of MSME credit distribution in 2018. 
TABLE III. RESULT OF ESTIMATION FOR MSME CREDIT DISTRIBUTION IN 2018

\begin{tabular}{|c|c|c|c|}
\hline & Medium & Low & High \\
\hline Commercial Bank & $32.45 \%$ & $31.87 \%$ & $33.12 \%$ \\
\hline $\begin{array}{c}\text { Foreign Exchange Private } \\
\text { National Bank }\end{array}$ & $24.27 \%$ & $23.69 \%$ & $24.94 \%$ \\
\hline $\begin{array}{l}\text { Non Foreign Exchange } \\
\text { Private National Bank }\end{array}$ & $24.96 \%$ & $24.38 \%$ & $25.63 \%$ \\
\hline Joint Venture Bank & $6.15 \%$ & $5.57 \%$ & $6.82 \%$ \\
\hline Foreign Bank & $2.25 \%$ & $1.67 \%$ & $2.92 \%$ \\
\hline Regional Development Bank & $21.45 \%$ & $20.87 \%$ & $22.12 \%$ \\
\hline
\end{tabular}

The equation can be used to express the MSME credit distribution for commercial banks in general. A different equation is used for each bank group due to the different coefficient.

Since regression model applied is LSDV model, the result of regression test is able to present characteristics of each individual to MSME credit distribution. The reference base used in this research is Bank Persero, a state owned bank group. The entire bank group represented by a dummy variable has negative coefficient, which means the MSME credit distribution by the groups of foreign exchange private national banks, non-foreign exchange private national banks, joint venture banks, foreign banks, and regional development banks is smaller than that of the state owned banks. This occurs because bank groups differ in their business focus which affects each bank's credit distribution. Estimation results shown in Table 2 indicate that only two banks have not been able to achieve the MSME target credit distribution. The two bank groups are the joint venture bank group and foreign bank group.

Fig. 3. shows that the largest MSME credit distribution is made by state-owned bank group; the proportion actually almost reaches $50 \%$. With the proportion that covers nearly half of the entire credit issued, it indicates that state-owned bank group has advantages in human resource and infrastructure in reaching MSME clients.

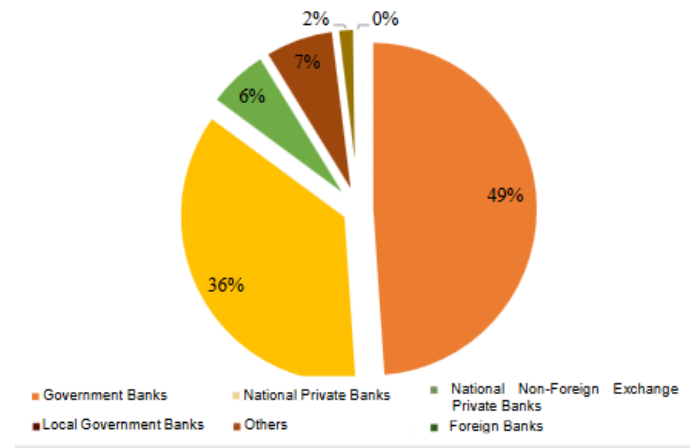

Fig. 3. Proportion of MSME Credit Distribution by Commercial Banks Source: [13]

The foreign bank group and the joint venture bank group have a very small proportion that is barely visible in the diagram. This fact should be considered by the government, or the central bank in relation to issuing and applying regulations. Additionally, other government policies do not provide adequate support for the implementation of Peraturan Bank Indonesia (PBI) regarding MSME credit. One of the policies concerns on the MSME credit distributing banks through Kredit Usaha Rakyat (KUR)/Credit for People Business. In 2015, KUR-distributing bank group was reduced to merely three banks, all state-owned bank group. Therefore it is not surprising that the distribution of MSME credit in that bank group has a very dominating portion.

The implementation of reward and punishment system in this regulation also needs to be reviewed. Bank Indonesia stated in PBI no. 17/12/PBI/2015 concerning the Distribution of MSME Credit that there are incentives and disincentives for target achieving banks and for those not achieving the target. The incentives are related to the amount minimum statutory reserves or currently known as Loan to Funding Ratio. BI will provide flexibility additional $2 \%$ in comparison to $92 \%$ previously allowed under the condition that the bank has less than 5\% MSME NPL points. Disincentives include reduction of the current account service as much as $0.5 \%$.

Although such incentives and disincentives have been implemented, in June 2016 only 64 banks achieved the target for the proportion of the MSME credit [14]. This indicates that the target was not appropriately set for each bank group. For the foreign bank group and joint venture bank group, the incentives offerred by BI are not interesting enough since both bank groups already achieved more than $100 \%$ LFR points; as much as $127 \%$ for the joint venture banks and $123 \%$ for the foreign banks. Consequently the two bank groups are not particularly interested in distributing the MSME credit.

In this case Bank Indonesia has to find out the condition of bank performance and the condition of economy where the bank puts into consideration in distributing MSME credit. It is implemented so that the regulation does not seem like it is being imposed on the entire bank group and so that the credit being distributed can be maximized.

\section{CONCLUSION}

The number of banks that is allowed distributing subsidized KUR is already increasing to 33 banks since the research started in 2015. This indicates that the government seriously targeted MSME to grow faster through subsidized loan. The research shows that only two (2) variables significantly affect the proportion of MSME credit distribution.

(1) the Non-Performing Loan (NPL) of MSME Credit which have negative effects to the proportion of MSME credit distributed by the bank, and

(2) Third Party Fund (TPF) also has negative effects to the proportion of MSME credit distributed by banks.

The conclusion that can be drawn from this research is that, from the side of credit offer, the bank performance has minor effect on the proportion of credit allocated to MSME. Therefore the central bank can actually force the commercial banks to increase the proportion of MSME credit distribution in order to achieve the $20 \%$ target, such as: 
1. For the foreign bank group and the joint venture bank groups, the decision of the central bank to give the flexibility related to the concession of non-oil sector export credit into the estimation of MSME credit is considered to be quite appropriate. Such as to make foreign banks and joint venture banks able to reach the set target.

2. Since the incentives and disincentives of achieving the target are not strong, Bank Indonesia should further review the regulation if Bank Indonesia insists on implementing the target for all bank groups. A stronger penalty could be given, consider the MSME credits, such as KUR already subsidized and protected with loan insurance for bad debt.

\section{REFERENCES}

[1] A.N. Berger and G.F. Udell, "Small business credit availability and relationship lending: The importance of bank organisational structure", Economic Journal, vol. 112, no. 477, pp. F32-F53, 2002. doi: 10.1111/1468-0297.00682.

[2] Bank Indonesia, Monetary Policy Report, 2nd Quarter 2016 [Laporan Kebijakan Moneter: Ekonomi, Moneter, dan Keuangan, Triwulan II 2016], Bank Indonesia, 2016.

http://www.bi.go.id/id/publikasi/kebijakan-

moneter/tinjauan/Documents/Laporan\%20Kebijakan\%20Moneter\%20Tr iwulan\%20II\%202016.pdf.

[3] K. Brunner and A.H. Meltzer, "A credit market theory of the money supply and an explanation of two puzzles in U.S. monetary policy", Rivista Internazionale di Scienze Economiche, 1966.

[4] D.M. Jaffee, "Credit rationing and the commercial-loan market", The Journal of Finance, vol. 24, no. 4, p. 729-, 1969. Doi: doi:10.1111/j.1540-6261.1969.tb00401.x
[5] F.S. Mishkin, The economics of money, banking, and financial markets, Columbia: Pearson Addison Wesley, 2004

[6] J.E. Stiglitz and A. Weiss, "Credit Rationing in Markets with Imperfect Information", The American Economic Review, vol. 71, no. 3, pp. 393410, Jun. 1981.

[7] Bank Indonesia, Credit crunch di Indonesia setelah krisis: fakta, penyebab, dan implikasi kebijakan [Credit crunch in Indonesia after the crisis: facts, causes, and policy implications], Direktorat Riset Ekonomi dan Kebijakan Moneter, Bank Indonesia, 2001.

[8] K.S.R. Rao, A. Das, and A.K. Singh, "Commercial bank lending to small-scale industry”, Economic and Political Weekly, vol. 41, no. 11, pp. 1025+1027-1033, Money, Banking and Finance (Mar. 18-24, 2006).

[9] Viverita, A.W. Lubis, Y. Bustaman, and R.S. Riyanti, "Foreign bank entry and credit allocation to SMEs: Evidence from ASEAN countries", Procedia - Social and Behavioral Sciences, vol. 211, pp. 1049-1056, 2015. doi: https://doi.org/10.1016/j.sbspro.2015.11.140.

[10] C. Nuryakin and P. Warjiyo, "Perilaku penawaran kredit bank di Indonesia: Kasus pasar oligopoli periode Januari 2001-Juli 2005 [Bank's credit offerings behaviour in Indonesia: Case of oligopoly market for the period January 2001-July 2005]", Buletin Ekonomi Moneter dan Perbankan, vol. 9, no. 2, pp. 21-56, 2006.

[11] J.E. McNulty, M. Murdock, and N. Richie, "Are commercial bank lending propensities useful in understanding small firm finance?", Journal of Economics and Finance, vol. 37, no. 4, pp. 511-527, 2011. doi: https://doi.org/10.1007/s12197-011-9191-x.

[12] D.N. Gujarati and D.C. Porter, Basic econometrics, 5th ed., New York: McGraw-Hill/Irwin, 2009.

[13] Bank Indonesia, MSME Credit Report [Laporan Kredit UMKM], 2015. http://www.bi.go.id/id/umkm/kredit/laporan/Default.aspx.

[14] Otoritas Jasa Keuangan, Statistik Perbankan Indonesia - Februari 2016 [Indonesian Banking $\quad$ Statistics 2016], 2016. http://www.ojk.go.id/id/kanal/perbankan/data-dan-statistik/statistikperbankan-indonesia/Documents/Pages/Statistik-Perbankan-IndonesiaFebruari-2016/SPI\%20Feb\%202016.zip. 